\title{
Nickel-Graphene Nanostructures: Synthesis, Study and Applications
}

\author{
Alexey A. Volodin, ${ }^{@}$ Artem A. Arbuzov, Pavel V. Fursikov, and Boris P. Tarasov \\ Institute of Problems of Chemical Physics RAS, 142432 Chernogolovka, Moscow region, Russia \\ ${ }^{\circledR}$ Corresponding author E-mail: alexvol@icp.ac.ru
}

\begin{abstract}
Here we present the results of our works on the development of new functional composites of graphene structures with metals, alloys, intermetallic compounds and their hydrides, and on the creation on their basis of hydrogen-storage materials for compact and safe hydrogen storage, electrode materials for nickel-metal hydride batteries, highly efficient catalysts for the hydrogenation of metals and organic compounds as well as hydrogen systems for energy backup and storage.
\end{abstract}

Keywords: Graphene, nanoparticles, metal, composite, hydrogen storage, hydrogen energy.

\section{Никель-графеновые наноструктуры: синтез, исследование и применение}

\author{
А. А. Володин, ${ }^{@}$ А. А. Арбузов, П. В. Фурсиков, Б. П. Тарасов \\ Институт проблем химической физики РАН, 142432 Черноголовка, Россия \\ @E-mail: alexvol@icp.ac.ru
}

\begin{abstract}
Представлены результаты работ авторов по созданию новых функциональных композитов графеновых структур с металлами, сплавами, интерметаллическими соединениями и их гидридами, а также по созданию на их основе материалов для компактного и безопасного хранения водорода, электродных материалов для никель-металлогидридных батарей, высокоэффективных катализаторов гидрирования металлов и органических соединений, водородных систем для резервного копирования и хранения энергии.
\end{abstract}

Ключевые слова: Графен, наночастицы, металл, композит, накопление водорода, водородная энергия.

\section{Introduction}

The most important task of hydrogen materials science and hydrogen energy technologies concerns the development of efficient hydrogen-accumulating materials and catalysts for the processes involving molecular hydrogen including hydrogenation catalysts of various compounds. Until now numerous studies have considered graphene and graphene-like materials (GLM) as promising carriers of nanosized metal and metal oxide catalysts to be used for the development of and functional catalytic composites. ${ }^{[1]}$ GLM have layered structure of $\mathrm{sp}^{2}$ hybridized carbon atoms arranged in a two-dimensional hexagonal lattice. ${ }^{[2]}$ The most promising techniques for the formation of metal-containing graphene composites include simultaneous reduction of graphite oxide and growth of metal nanoparticles. ${ }^{[3]}$ Combining high specific surface area of 2D graphene-like component and its high thermal conductivity as well as high catalytic activity of nanosized metal particles supported on GLM, such metal-graphene composites are highly active additives in production of hydrogen storage materials and capable to serve as catalysts for hydrogenation of various organic compounds. ${ }^{[4]}$ The aim of the present work was to describe in detail the synthesis of new nickelgraphene nanostructures, as well as to demonstrate various applications of the obtained composite materials, including catalysis, reversible sorption and storage of hydrogen, chemical power sources and hydrogen energy storage.

\section{Experimental}

Graphite oxide (GO) was obtained from natural graphite GK-1 (ash content $\leq 1 \mathrm{wt} \%$, State standard 4404-78) according 
to the procedure described in ${ }^{[5]}$. GLMs were obtained by thermal reduction of GO in a tubular furnace. Dried GO $(10 \mathrm{mg})$ was placed in the medium part of a quartz reactor under the flow of argon at a rate of $0.2 \mathrm{~L} / \mathrm{min}$, and the reactor was rapidly transferred to a tubular furnace heated up to $900{ }^{\circ} \mathrm{C}$. In $3-5 \mathrm{~s}$, GO was subject to explosive decomposition to produce gaseous $\mathrm{CO}, \mathrm{CO}_{2}$, and $\mathrm{H}_{2} \mathrm{O}$. The solid product (considerably increased in volume) was removed from the hot zone with the argon flow. The obtained powder was annealed in the atmosphere of argon at $900{ }^{\circ} \mathrm{C}$ for $3 \mathrm{~h}$.

The Ni-graphene composite was prepared by simultaneous reduction of $\mathrm{GO}$ and nickel(II) from the mixture prepared previously by freeze drying of $\mathrm{GO}$ dispersion in $\mathrm{Ni}\left(\mathrm{CH}_{3} \mathrm{COO}\right)_{2}$ aqueous solution. For this purpose, the GO aqueous suspension together with the corresponding amount of $\mathrm{Ni}\left(\mathrm{CH}_{3} \mathrm{COO}\right)_{2} \cdot 4 \mathrm{H}_{2} \mathrm{O}$ were processed in an ultrasonic bath for $60 \mathrm{~min}$. The obtained mixture was placed in a $1 \mathrm{~L}$ pear-shaped flask and frozen by placing the flask in a dewar filled with liquid nitrogen. Then water vapors above the ice were removed at ambient conditions by a vacuum pump $\left(\sim 1 \cdot 10^{-3} \mathrm{~atm}\right)$ equipped with a nitrogen trap until the mixture was completely dry. The reduction of the dried mixture was performed in a $40 \mathrm{~mm}$ tubular reactor at $300-500{ }^{\circ} \mathrm{C}$ in the flow of $\mathrm{H}_{2}$ (with the rate of $200 \mathrm{~mL} / \mathrm{min}$ ) for $30 \mathrm{~min}$. The obtained nickel-graphene composites contained from 5 to $60 \mathrm{wt} \%$ of $\mathrm{Ni}$ nanoparticles.

Hydrogenation of $\mathrm{Mg}$ and magnesium-graphene composites was carried out by mechanochemical method: the required amount of graphene material, $1 \mathrm{~g}$ of $0.5-1 \mathrm{~mm}$ magnesium powder, and $10 \mathrm{~mm}$ steel balls (the sample-to-balls mass ratio was 1:40) were placed in a $80 \mathrm{~mL}$ steel grinding beaker in a dry argon box. The beaker was then sealed with a special lid equipped with an intake valve, removed from the argon box, evacuated to $6.5 \cdot 10^{-5}$ atm, and filled with $99.9999 \%$ pure hydrogen until 25 atm. The hydrogenation was carried out in a Pulverisette 6 planetary ball mill, the rotational speed of the grinding bowl being 500 $\mathrm{rpm}$, and hydrogen pressure $25 \mathrm{~atm}$. The hydrogenation rate was determined by the fall of hydrogen pressure (accurate to $0.2 \mathrm{~atm}$ ) every hour of mechanochemical processing.

The catalytic synthesis of CNF was performed in a horizontal tubular flow reactor at the atmospheric pressure and the temperature of $700{ }^{\circ} \mathrm{C}$. A $50 \mathrm{mg}$ batch of $\mathrm{Ni}\left(\mathrm{CH}_{3} \mathrm{COO}\right)_{2} / \mathrm{GO}$ composite was placed in a quartz boat in the cold zone of the reactor outside the furnace. The reactor was heated in the flow of gas mixture Ar: $\mathrm{H}_{2}: \mathrm{C}_{2} \mathrm{H}_{4}=1: 3: 1.6$. After the operating temperature had been reached, the quartz boat was moved to the hot zone of the reactor. The synthesis time varied from 1 to $60 \mathrm{~min}$. After the synthesis, the boat was moved to the cold zone of the reactor. Then the sample was cooled to room temperature in the flow of argon.

The obtained composites were characterized by a complex of physicochemical methods. Thermogravimetric analysis and differential scanning calorimetry were performed at $30-1000^{\circ} \mathrm{C}$ with the linear heating rate of $5 \mathrm{grad} / \mathrm{min}$ using NETZSCH STA 409 $\mathrm{C}$ Luxx thermal analyzer. The elemental composition was deter- mined by a Vario Micro cube CHNS/O analyzer. IR spectra were recorded on a Perkin-Elmer Spectrum 100 Fourier spectrometer in the interval of $450-4000 \mathrm{~cm}^{-1}$. The specific surface was measured by the BET method at the temperature of liquid nitrogen using SORBI-MS analyzer. The X-ray diffraction phase analysis was carried out on DRON-UM2 and SIEMENS D500 diffractometers. The micrographs of the studied materials were obtained with a Zeiss LEO SUPRA scanning electron microscope and a JEOL JEM2100 transmission electron microscope.

\section{Results and Discussion}

The metal-graphene (Ni/GLM) composites prepared by the co-reduction of the mixtures of graphite oxide with nickel salts are shown in Figures 1, 2. ${ }^{[6,7]}$

The Ni/GLM composites were then used to prepare three-dimensional structures of the graphene-nanotube and graphene-nanofiber type with a high specific surface area by growing carbon tubular nanostructures via catalytic decomposition of hydrocarbons. It was found that the catalytic decomposition of ethylene on $\mathrm{Ni} / \mathrm{GLM}$ at temperatures of $500-700{ }^{\circ} \mathrm{C}$ leads to the formation of CNFs on the surface of the metal-graphene nanosheets. The resulting CNFs have diameters ranging from 5 to $20 \mathrm{~nm}$, and the length increases from 5 to $300 \mathrm{~nm}$ with an increase in the synthesis time from 1 to $60 \mathrm{~min}$ (Figure 3). Mechanism of the formation of nickel-carbon-graphene composites was determined. The process consists of four stages: 1) the reduction of graphite oxide and nickel ions; 2 ) the formation and growth of $\mathrm{Ni}$ clusters on reduced graphite oxide; 3) the catalytic pyrolysis of $\mathrm{C}_{2} \mathrm{H}_{4}$ on $\mathrm{Ni}$ single crystals supported on a graphene-like support; and 4) the formation and growth of carbon nanostructures on the surface of the graphene-like material. Such three-dimensional structures having a high specific surface area (more than $700 \mathrm{~m}^{2} / \mathrm{g}$ ) are considered to be perspective as gas sorbents, supports of metal catalysts, and components of electrically conductive composites. ${ }^{[8]}$

Nickel-graphene catalysts were utilized to prepare highly efficient magnesium-based hydrogen storage materials with a reversible hydrogen storage capacity of more than 6.5 wt. \%. ${ }^{[9,10]}$ The addition of Ni/GLM promotes an increase in the rate of Mg hydrogenation due to the high catalytic activity of nanosized $\mathrm{Ni}$ in the dissociation reaction of $\mathrm{H}_{2}$ molecules, while the GLM coating of highly dispersed $\mathrm{MgH}_{2}$ particles retains the submicron size of the Mg particles formed during the dehydrogenation and provides high

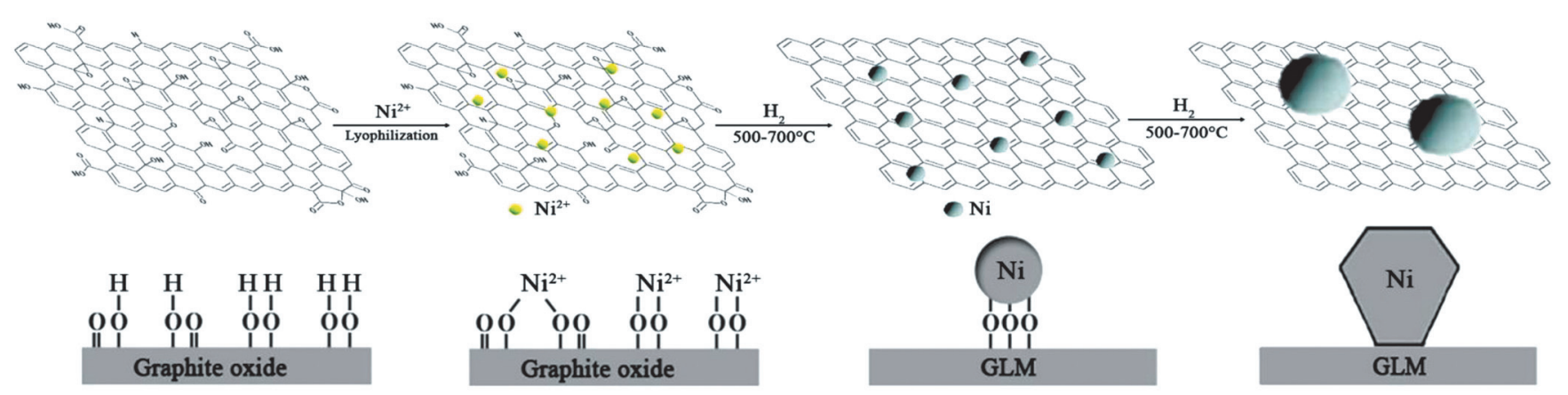

Figure 1. Preparation scheme of Ni-graphene composites. 


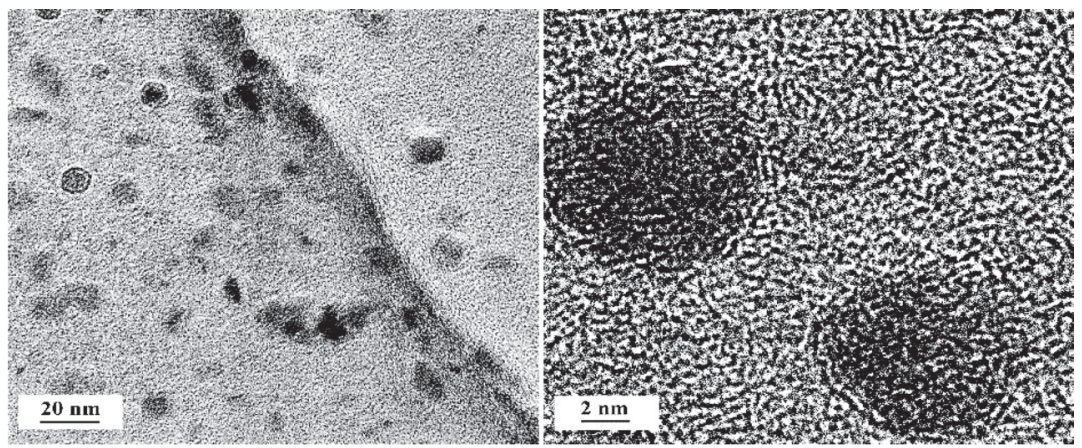

Figure 2. TEM micrographs of the Ni/GLM composites.
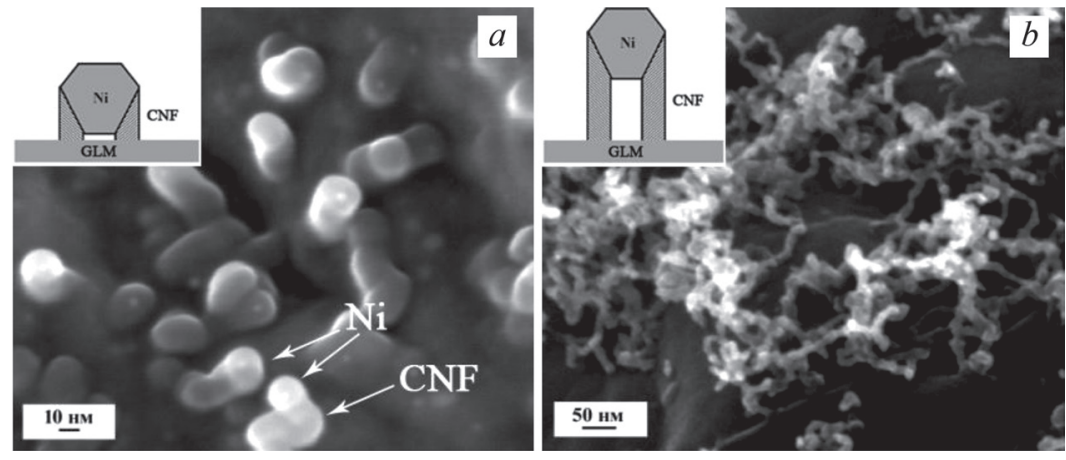

Figure 3. SEM micrographs of the CNF/GLM composites synthesized during 1 (a) and 60 (b) min.

thermal conductivity of $\mathrm{Mg} / \mathrm{MgH}_{2}+\mathrm{Ni} / \mathrm{GLM}$ composites (Figure 4).

The optimal methods were identified to prepare heatconductive intermetallic-graphene composites, including the $\mathrm{Mg}_{2} \mathrm{Ni} / \mathrm{Mg}+\mathrm{GLM}$ composite. An increase in the thermal conductivity of powder hydrides of intermetallic compounds is facilitated by the addition of up to $5 \mathrm{wt}$ \% of GLM under mechanochemical treatment in a ball mill in a hydrogen environment. The coating of metal particles with graphene ensures good thermal conductivity and reduces the sintering of the metal particles during the heating processes. Topological features of microstructure of the composites (in which the magnesium, the intermetallic compound, and the GLM particles with characteristic sizes less than $1 \mu \mathrm{m}$ are in direct contact) being largely unchanged during cycling contribute to the improvement of hydrogen sorption proper- ties of the materials. Such composites reversibly absorb 5 wt. \% hydrogen at a high rate $(90 \%$ is absorbed in $5 \mathrm{~min}$ at $300{ }^{\circ} \mathrm{C}$ ). The resulting composites are easy to press, which is convenient to fabricate portable metal hydride batteries and hydrogen generators.

Nickel-metal hydride (Ni-MH) power sources are widely used in portable electronic devices due to their high energy density, cyclic stability, resistance to overcharging and good environmental compatibility. The efficiency of the Ni-MH power source depends on the cathode and anode materials, the method of electrode preparation etc. $\mathrm{AB}_{5}, \mathrm{AB}_{3}$, and $\mathrm{AB}_{2}$ type alloys are widely used as working materials for Ni-MH power sources. ${ }^{[11]}$ One of the problems in the operation of anode materials is the low conductivity. The conductivity of pure magnesium is $2.27 \cdot 10^{7} \mathrm{~S} / \mathrm{cm}$, and its hydride $\left(\mathrm{MgH}_{2}\right)$ is $10^{-18}-10^{-12} \mathrm{~S} / \mathrm{cm}$. $\mathrm{Ni}(\mathrm{OH})_{2}$ is used
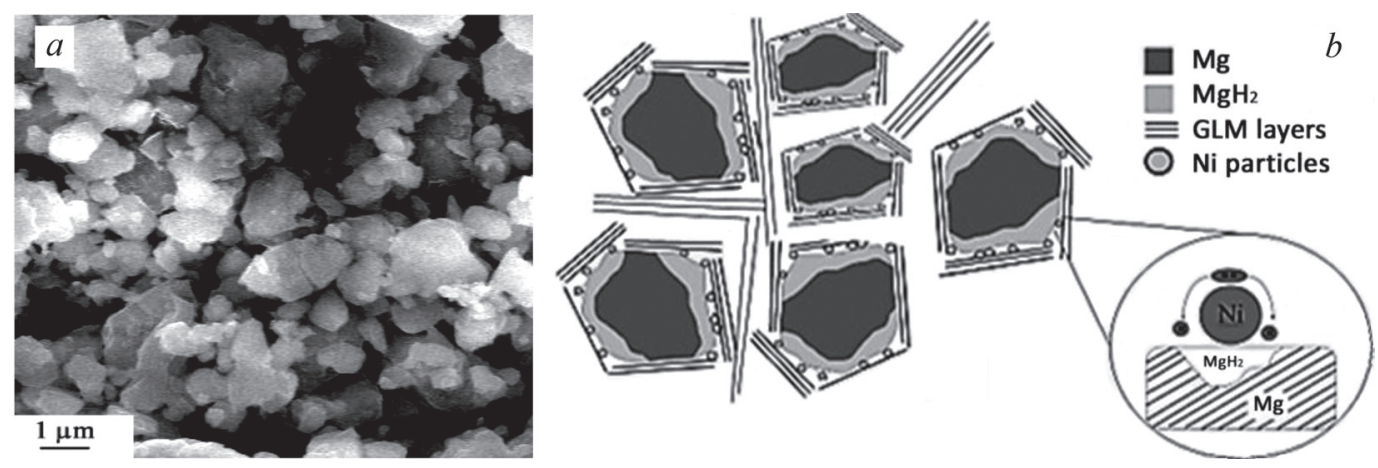

Figure 4. SEM micrograph (a) and schematic layout (b) of the $\mathrm{MgH}_{2}+\mathrm{Ni} / \mathrm{GLM}$ composite. 
as the cathode material in all Ni-based power sources due to its low cost and good performance. However $\mathrm{Ni}(\mathrm{OH})_{2}$, has a very low conductivity $\left(10^{-14}-10^{-8} \mathrm{~S} / \mathrm{cm}\right)$. Acetylene carbon black or graphite is usually added to improve the conductivity of electrode materials. It is necessary to introduce these additives in large quantities, which reduces the capacity of the electrodes, for a small amount does not lead to the desired effect.

In our works we studied Carbon/Metal hydride and Carbon/Hydroxide composites as promising materials for the development of advanced Ni-MH power sources. The efficiency of using combined Ni/GLM/MH composites to achieve maximum performance, both for reversible hydrogen sorption and for Ni-MH power sources, has also been found. Electroconductive composites of $\mathrm{Ni}(\mathrm{OH})_{2}$ and metal hydrides with various carbon materials - graphite $(\mathrm{G})$, carbon nanotubes (CNT), carbon nanofibers (CNF), and graphene like material (GLM) were prepared by mechanochemical treatment of the corresponding mixtures in a ball mill (Figure 5). It is shown that the conductivity of $\mathrm{Ni}(\mathrm{OH})_{2}$ with carbon nanostructures (3 wt. \%) is much higher than that of the hydroxide with graphite (Table 1). The addition of carbon nanomaterials to $\mathrm{Ni}(\mathrm{OH})_{2}$ increases the electrical conductivity by seven orders of magnitude. Electrodes for nickel-metal hydride batteries were fabricated on the basis of the developed electroconductive metal hydride-graphene and nickel hydroxide-graphene composites. ${ }^{[12]}$ The capacity of such electrodes is $20 \%$ higher than that of currently used electrodes.

The hydrogen based energy storage is beneficial in energy intensive systems $(\geq 10 \mathrm{kWh}$ ) operating in a wide range of unit power (1-200 kW), especially when the foot- print of the system has to be limited. The main challenge hindering implementation of the hydrogen energy storage systems is safe and efficient hydrogen storage and supply. ${ }^{[13,14]}$ To respond to the challenge hydrogen storage in metal hydrides can be used as a promising option for small-to medium-scale applications $\left(0.01-30 \quad \mathrm{Nm}^{3} \mathrm{H}_{2}\right) \cdot{ }^{[15-18]}$ Our studies on practical application of the GLM-based composites have also been focused on the development of metal hydride hydrogen storage tanks, the performances of which were found to be significantly improved with the use of the composites of metal hydrides with GLM supported metal catalysts, ${ }^{[19,20]}$ making them suitable to fabricate prototypes of hydrogen energy backup and storage systems (Figure 6). ${ }^{[16]}$

\section{Conclusions}

The work was focused on the development of advanced highly efficient hydrogen storage and hydrogen generation composite materials based on hydride forming metal phases coated with metal-graphene structures. In these composites, metal-graphene materials perform at least 3 functions: 1) to serve as hydrogenation catalysts, providing easy dissociation of hydrogen molecules, 2) to increase the thermal conductivity of the composite materials, 3) to prevent the sintering of highly dispersed metal particles during high-temperature decomposition of hydride phases. On the basis of the developed hydrogen storage and hydrogen generation composite materials, compact and safe hydrogen storage tanks with high performances, as well as prototypes of nickel-metal hydride batteries were created.
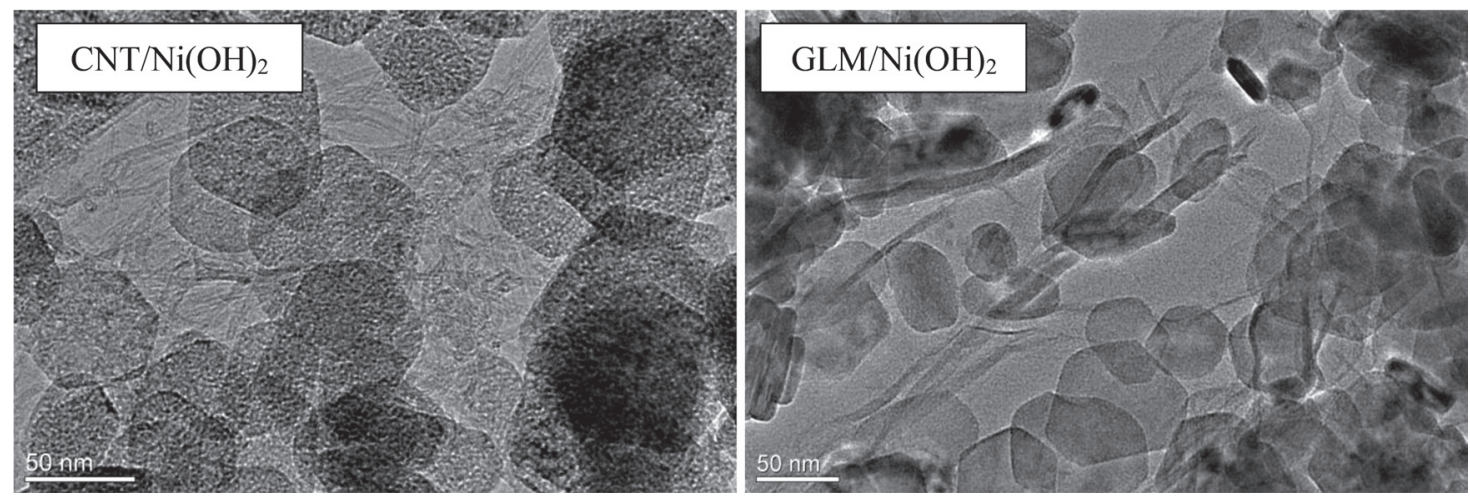

Figure 5. TEM micrographs of the carbon/nickel hydroxide composites.

Table 1. Characteristics of the carbon (3 wt. \%)/nickel hydroxide composite electrodes.

\begin{tabular}{cccccc}
\hline Component & $\mathrm{g} / \mathrm{cm}^{3}$ & Dimensions & Composite & $\mathrm{S} / \mathrm{cm}$ & $\mathrm{mAh} / \mathrm{g}$ \\
\hline $\mathrm{Ni}(\mathrm{OH})_{2}$ & 3.45 & particule size $50 \mathrm{~nm}$ & $\mathrm{Ni}(\mathrm{OH})_{2}$ & $3.7 \cdot 10^{-9}$ & 100 \\
$\mathrm{G}$ & 2.24 & particule size $30 \mu \mathrm{m}$ & $\mathrm{Ni}(\mathrm{OH})_{2} / \mathrm{G}$ & $1.3 \cdot 10^{-7}$ & 145 \\
$\mathrm{CNT}$ & 1.61 & diameter $1-5 \mathrm{~nm}$ & $\mathrm{Ni}(\mathrm{OH})_{2} / \mathrm{CNT}$ & $3.9 \cdot 10^{-3}$ & 265 \\
$\mathrm{CNF}$ & 1.39 & diameter $20-30 \mathrm{~nm}$ & $\mathrm{Ni}(\mathrm{OH})_{2} / \mathrm{CNF}$ & $6.8 \cdot 10^{-3}$ & 220 \\
$\mathrm{GLM}$ & 1.48 & layers $2-5$ stack height $1-10 \mathrm{~nm}$ & $\mathrm{Ni}(\mathrm{OH})_{2} / \mathrm{GLM}$ & $8.9 \cdot 10^{-2}$ & 195 \\
\hline
\end{tabular}




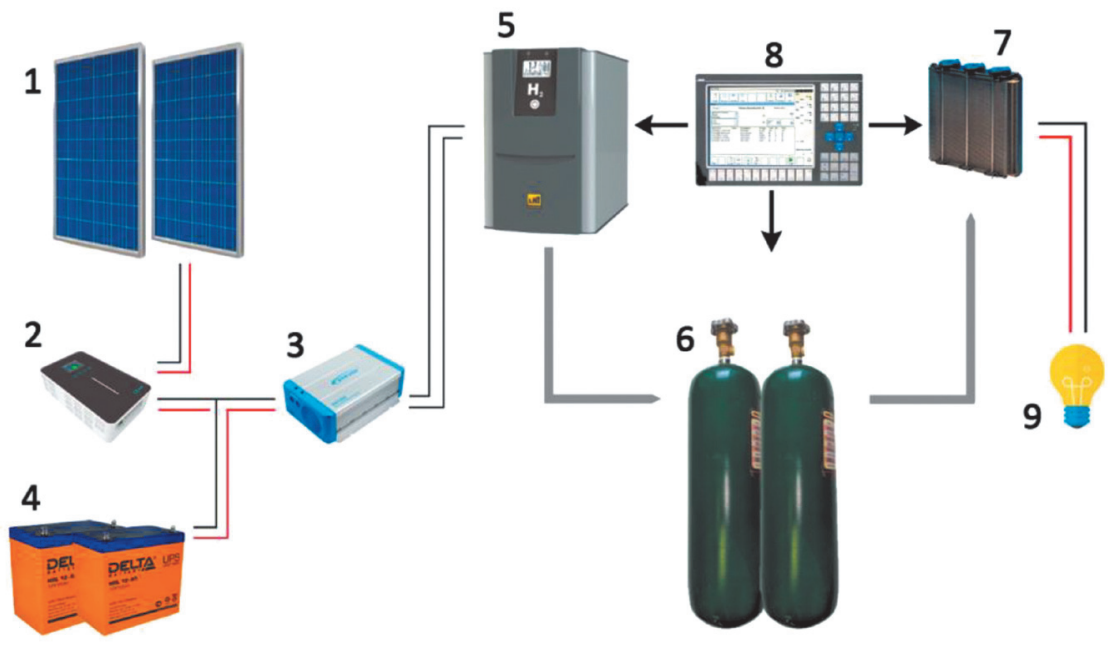

Figure 6. Hydrogen energy storage system: 1 - Seraphim Blade SRP-280-BPB 48 V solar panels, which serve as a renewable energy source. 2 - I-Panda RUNNER charge controller (max 60 A 48 V); 3 - EPsolar Epever SHI1000 invertor ( 220 V, 50 Hz), 4 - Delta HRL $24 \mathrm{~V}$ lead-acid batteries, 5 - HG Pro 1500 electrolyzer $\left(640 \mathrm{~W}, 13\right.$ bar $\mathrm{H}_{2}$ output pressure, max $90 \mathrm{Nl} / \mathrm{h} \mathrm{H}_{2}$ output flow rate), 6 - developed by the authors metal hydride hydrogen storage units $\left(2 \times 3.2 \mathrm{Nm}^{3}, 1.15\right.$ bar $\mathrm{H}_{2}$ pressure and $13 \mathrm{Nl} / \mathrm{min}_{2}$ flow rate in the output pipeline); 7 - Ballard FCGen 1020ACS max. 1.2 kW hydrogen-air fuel cell; 8 - automatic control system; 9 - a load.

The hydrogen storage tanks were tested as part of an original integrated hydrogen energy storage system, where solar panels generate electricity, the surplus of which is used to produce hydrogen by water electrolysis, the hydrogen is stored in the developed devices, and, if necessary, is oxidized in fuel cells to produce on-demand electricity.

Acknowledgements. This work was carried out within the State Assignment No. AAAA-A19-119061890019-5 and with the financial support of the Russian Foundation for Basic Research (Grant No. 19-03-01069).

\section{References}

1. Arbuzov A.A., Mozhzhuhin S.A., Volodin A.A., Fursikov P.V., Tarasov B.P. Russ. Chem. Bull. 2016, 65, 1893-1901.

2. Huang X., Yin Z., Wu Sh., Qi X., He Q., Zhang Q., Yan Q., Boey F., Zhang H. Small 2011, 7, 1876-1902.

3. Bai H., Li Ch., Shi G. Adv. Mater. 2011, 23, 1089-1115.

4. Soo L.T., Loha K.Sh., Mohamada A.B., Dauda W.R.W., Wong W.Y. Appl. Catal. A 2015, 497, 198-210.

5. Arbuzov A.A., Muradyan V.E., Tarasov B.P. Russ. Chem. Bull. 2013, 9, 1962-1966.

6. Arbuzov A.A., Mozhzhuhin S.A., Volodin A.A., Fursikov P.V., Tarasov B.P. Patent RU2660232C1 (15.06.2016).

7. Arbuzov A.A., Kluyev M.V., Kalmykov P.A., Tarasov B.P., Magdalinova N.A., Muradyan V.E. Patent RU2551673C1 (27.12.2013).
8. Arbuzov A.A., Volodin A.A., Tarasov B.P. Russ. J. Phys. Chem. A 2020, 94, 984-989.

9. Tarasov B.P., Arbuzov A.A., Mozhzhuhin S.A., Volodin A.A., Fursikov P.V., Lototskyy M.V., Yartys V.A. Int. J. Hydrogen Energy 2019, 44, 29212-29223.

10. Arbuzov A.A., Mozhzhuhin S.A., Volodin A.A., Fursikov P.V., Tarasov B.P. Patent RU2675882C2 (21.12.2016).

11. Hannan M.A., Hoque M.M., Mohamed A., Ayob A. Renew. Sust. Energ. Rev. 2017, 69, 771-789.

12. Volodin A.A., Fursikov P.V., Fokina E.E., Tarasov B.P. Russ. J. Phys. Chem. A 2020, 94, 1017-1023.

13. Müller K, Arlt W. Energy Technology 2013, 1, 501-511.

14. Zhang F., Zhao P., Niu M., Maddy J. Int. J. Hydrogen Energ. 2016, 41, 14535-14552.

15. Tarasov B.P., Lototskii M.V., Yartys V.A. Russ. J. Gen. Chem. 2007, 77, 694-711.

16. Tarasov B.P., Fursikov P.V., Volodin A.A., Bocharnikov M.S., Shimkus YuYa., Kashin A.M., Yartys V.A., Chidziva S., Pasupathi S., Lototskyy M.V. Int. J. Hydrogen Energ. 2021, 46, 13647-13657.

17. Lototskyy M.V., Davids M.W., Tolj I., Klochko Y.V., Satya Sekhar B., Chidziva S., Smith F., Swanepoel D., Pollet B.G. Int. J. Hydrogen Energ. 2015, 40, 11491-11497.

18. Han G., KwonY.K., Kim J.B., Lee S., Bae J., Cho E.A., Lee B.J., Cho S., Park J. Applied Energy 2020, 259, 114175.

19. Tarasov B.P., Kagan K.L., Fursikov P.V., Fokin V.N., Arbuzov A.A., Volodin A.A., Shimkus YuYa. Patent RU167781 (10.01.2017)

20. Tarasov B.P., Fursikov P.V., Fokin V.N., Arbuzov A.A., Volodin A.A., Mozhzhuhin S.A., Patent RU2729567 (07.08.2020). 